\title{
Culturally-biased Scientific Reporting
}

\section{Uriel Halbreich*}

Professor of Psychiatry, Director of Bio-behavioral Research, Jacobs school of

Medicine and Bio Medical Sciences (SMBS), University at Buffalo, the State

University of New York (SUNY-AB), USA

*Corresponding Author: Uriel Halbreich, Professor of Psychiatry, Director of

Bio-behavioral Research, Jacobs school of Medicine and Bio Medical Sciences

(SMBS), University at Buffalo, the State University of New York (SUNY-AB), USA.
Received: February 16, 2021

Published: : March 15, 2021

(C) All rights are reserved by Uriel Halbreich.
The COVID-19 Pandemic and its consequences illuminates the globalization of the crisis but also differences and discrepancies in reporting the data as well as in their interpretations. From the outset the magnitude of the problem and its spread were assessed according to political interests. Public-Health responses were also implemented according to politics and compliance has been linked to communities' and individuals' preconceived social biases. It is apparent that "the numbers do not speak for themselves"-they are filtered, amplified or suppressed, through the megaphones of their reporters. Truth is in the eyes of the beholder.

This is not only an issue for Medical science. One of my first experiences of confronting mis-information was when as medical students during clinical years we were signed to serve at an emergency facility during the 1967 Israeli-Arab "Six days war". The Israeli news radio kept operational silence so we eagerly listened to the BBC which was considered to be neutral and reliable. The $\mathrm{BBC}$ reported that according to Egyptian army Headquarters Egyptian tanks are well inside Israel and are galloping Eastward toward Be`er Sheva. However, when helicopters brought casualties to our triage point our first question was "where are you coming from?", it was obvious that the front line was fast moving Westward and within two days the victorious Israeli army was on the Suez Canal and the Sinai battle was over. Not only that the Egyptian army Headquarters were unable to oversee the war based on reports of their field commanders, King Housein of Jordan relied on the $\mathrm{BBC}$, decided to seize the opportunity and joined the war to get his piece of the cake. We moved to the Jerusalem front were we received relatively few casualties because Jordan lost its occupied West Bank in two days.

The lesson that we had as front-line Medical students: believe your patients and facts on the ground (or in the helicopter) not the Media.

On a different level and a different context, the costume in Korea had been that once a research fellow went back to his/her home Institute they invited their mentor to help them in establishing their Academic careers.In one of my visits to a University Hospital in South Korea we systematically went from one department to another, each Professor joined the group procession to the next stop. By the time that we arrived at one of the surgical wards the group was 15-20 Professors strong. The Surgery Chairman presented behavioral issues in his practice and as a demonstration showed us an old Shillah brick that he had recently received from a grateful patient. The patient was a nationally-known archeologist who said that he excavated the antique at one of his sites. As such it would be very valuable. The Professor sent it for laboratory verification of authenticity at the National museum, when the Carbon Radioactive and imaging tests came back positive he sent it to another academic scientific laboratory who validated the results of the first tests. The numbers and conclusions reported by the two laboratories were similar. Never the less the surgeon was convinced that "it does not make sense" "even the most appreciative and grateful

Citation: Uriel Halbreich. "Culturally-biased Scientific Reporting". Acta Scientific Neurology 4.4 (2021): 13-14. 
patient would not give such an expensive museum-worthy gift". He went on detailing the reasons for his doubts until one of the group told him: if you are so convinced give the brick to Professor Halbreich. He had to "save face" with his colleagues and I had no choice but accepting the imposed gift. The brick is in my office as a reminder that sometimes in some Eastern cultures "saving face" and maintaining Harmony overcome apparent evidence-based facts. I tackled "saving face" situations in Asia, including during the SARS epidemic but also in the USA where attempts to avoid embarrassment influence disclosure of data.

In my own laboratory I had research fellows from many countries. Almost all did their best to please me but some, from certain cultures, went beyond niceties. They worked very hard for long hours but sometimes the results were different from what we hypothesized and expected. They preferred to say that this was not done yet instead of facing disappointment and disruption of harmony. It took some time to make them comfortable routinely going over raw data with no biases and differing interpretations.

For newcomers to the USA it is not easy to adapt to the American attitude stating that "everything is great"," it is amazing", "we are the most successful", "we know best", "no problem, it is cool" etc. I learnt it shortly before I arrived at the States. I was invited by Columbia University and Ruth Ginsburg who was then the counsel for Columbia worked on my H-1 Visa. We had to demonstrate that I am the only one qualified for the particular function and there is no US citizen who can do it. When I prepared a factual résumé Ruth advised "everybody inflates their achievements, when reading yours they would also assume that it is inflated, don `t be modest, add adjectives, this is America".

The attitude of "we know what is good for you, we give you money and you do what we tell you" may be exercised also in interactions between Americans and colleagues in need in other countries. Americans should know that people on the receiving side may know how to receive wisely. I witnessed such an occasion in a Middle-East University several years ago. During one of my repeated visits they also had a delegation from a prestigious American University who received private foundation funds to "eliminate global malaria". They offered substantial sum to the local faculty to serve as one of their sites. Following a morning persuasion and attentive listening the Medical school accepted the funds. When the delegation left we had lunch during which it was obvious that they did not have any patient with malaria for a long time. But, the outcome expected by the Americans will be achieved, by the end of the five years grant it would be demonstrated that there is no malaria in the region. The foundation and its "experts" will be happy and declare success. "We were generous, money well-spent and problem solved".

On a local level we may conceptually face a similar issue of presenting non-facts as facts and denying facts as non-existing. For example, I had a nurse whose job was to recruit patients for a clinical trial of a Neuropsychiatric medication. Our usual rate of confirmation of clinicians` diagnoses with Research Diagnostic Criteria (RDC) has been about 50\%. The external monitor noticed that this nurse was off the charts, her rate of agreement with the clinicians was almost perfect. Everybody was happy, the referring clinicians were proud that their diagnoses were correct and the nurse had an easy time and good relations with all personnel. But was it "great"? On paper initially it seemed so, in further examination facts were different. The outcome was fine because we carefully checked the facts and acted accordingly and did not take for granted non-factual reports.

As an interim conclusion :Local culture may influence reporting and perception of data on multiple levels. Starting from a local clinic and continuing all the way to National governments and International interactions. "Objectivity" and "Rational" are relative and subjective. The least that we may do is an attempt to a stark look at the raw numbers.

\section{Assets from publication with us}

- Prompt Acknowledgement after receiving the article

- Thorough Double blinded peer review

- Rapid Publication

- Issue of Publication Certificate

- High visibility of your Published work

Website: www.actascientific.com/

Submit Article: www.actascientific.com/submission.php

Email us: editor@actascientific.com

Contact us: +919182824667 